\title{
Storage System of Potato in Bangladesh
}

\author{
Pradip Hajong ${ }^{1}$, Md. Moniruzzaman ${ }^{2}$, M. Idris Ali Mia ${ }^{2}$, Md. Mostafizur Rahman ${ }^{3, *}$ \\ ${ }^{1}$ Bangladesh Agricultural Research Institute, Joydebpur, Gazipur \\ ${ }^{2}$ Department of Agribusiness \& Marketing, Bangladesh Agricultural University \\ ${ }^{3}$ Department of Agricultural Marketing \& Business Management, Sylhet Agricultural University \\ *Corresponding Author: mostafiz.sau2013@gmail.com
}

Copyright (C) 2014 Horizon Research Publishing All rights reserved.

\begin{abstract}
The study was undertaken to investigate the storage system and seasonal price variation of potato. Ten cold storage owners, 20 potato traders and 30 potato growers of Rangpur district in Bangladesh comprised the sample frame of the study. Both the primary and secondary data were collected. The primary data were collected through direct interview method with the help of pretested questionnaires during the months of August and September, 2011. Storing of potato in the cold storage plants certainly reduces the excessive losses of potato but all farmers can not avail the facility of cold storages due to several reasons, such as high cold storage charge, uncertainty of future market price, financial insolvency, bad communication and inadequate transport facilities and lack of any provision in getting compensation for damage of potato in the cold storage plants. Prices of potato began to increase by April and reached the peak in December. During the harvest period, potato price remained low and then it gradually rose up to the start of next harvesting period.
\end{abstract}

Keywords Storage system, Seasonal Price Variation, Potato

\section{Introduction}

Potato (Solanum tuberosum) is one of the important vegetables in human diet. Potato has been cultivated as a staple food in at least 40 countries of the world [1]. It is an important food crop from the very beginning of human civilization and occupying its position just after wheat and rice both in respect of production and consumption [2]. In Indian sub-continent the cultivation of potato was probably started during the $17^{\text {th }}$ century [3]. In Bangladesh the cultivation of potato was started in the late $19^{\text {th }}$ century [4]. At least in 100 countries of the world it is the most important vegetable. The economic problems in relation to any crop production in Bangladesh are varied and manifold. The growers have to sell major part of their produces immediately after harvesting at a very low price due to lack of storage facilities and cash need of the growers. This is known as distressed sale of the produce. Sometimes, ignorance of the growers about the prospect of future marketing of their produce becomes responsible for such type of selling. The growers are the most sufferers due to the existing storage problems of potato in Bangladesh and once they do not get enough economic gain, they may not retain much enthusiasm to go for potato cultivation for the following season. Therefore, it may legitimately be claimed that cold storage plants have a positive impact in augmenting potato production in the country and its emergence as a major cash crop has imperative impact on the national economy.

The trend to increase production of potato in Bangladesh is retarded mainly by post-harvest problems among which storage is an important one. At present two-thirds of the total produce do not find any space in the cold storage and a part of which is consumed shortly after harvest and the rest is kept in traditional storage at home under room temperature and humidity at farm level. These potatoes lose weight gradually and ultimately get shriveled, rotten or sprouted. Thus the quantity of potato is virtually reduced, in the long run, to less than 70 percent of the original production [5]. Rahman [6] in his study found that about 3 lakh tons of potato which is one third of the total annual production is wasted every year a mounting a loss of more than Taka 60 crores annually. According to Ahmad [7] and Alauddin [8] potato production is directly proportional to its preservation space. Therefore, if storage facilities are not increased, the production of potato cannot be increased considerably.

A few studies on economic aspect of cold storage have been conducted so far in Bangladesh. In a preliminary survey of the diseases of potatoes in cold storage in Bangladesh it was found that 2-9 percent of cold stored potatoes were lost in every year due to disease [9]. Fakir [10] stated that an amount of Taka 8 crores approximately was lost annually due to storage disease. Therefore, the emergence of the development of proper storage facilities for potato in Bangladesh is evident. Accordingly, the present study has been undertaken. It may be argued that this study will not only be helpful from academic and theoretical considerations, this should also have practical usefulness. The present study is designed to provide valuable information regarding 
comparative losses of potato stored under cold storage. The various results of the study will act as a basis for further studies on such problems and also will help as a guideline in the formation of future policies by public decision making authorities regarding the development of storage facilities in Bangladesh.The present study was undertaken with the specific objectives of examining the present storage system and seasonal price variation of potato.

\section{Methodology}

To examine the present storage system of potato, Rangpur district was chosen purposively. Because it is the leading zone in respect of cold storage plants installed and potato production in Bangladesh. Twenty three out of total 165 cold storage plants were located in Rangpur district. Ten cold storage plants, twenty traders and thirty potato growers were selected from the study area. Cold storage plants were selected through simple random sampling technique by applying lottery method for the study. At first a list of cold storage plants of Bangladesh along with storage capacity was collected from the Directorate of Agricultural Marketing of Bangladesh. The addresses of both site office and head office of each selected plant were collected from the office of Bangladesh Cold Storage Association situated in Dhaka. Twenty potato traders were purposively selected who were engaged in potato business in the year 2010 and had stored their purchased potato partly or full amount in cold storages during the period between buying and selling. Thirty potato growers who cultivated potato in the crop year 2009-10 were selected from Sadar upazilla of Rangpur district. Stratified random sampling technique was followed to select the potato growers. Strata of the potato growers were done according to their own cultivated holdings into small (up to 2 acres), medium (2.01-4.00 acres) and large (above 4.00 acres). Fifteen small farmers, eight medium farmers and seven large farmers were selected which comprised the sample of potato growers.

Both primary and secondary data were used to fulfill the objectives of the study. The researcher himself conducted the survey and collected primary data through direct interviews with the respondents during the period from third week of August to September, 2011. Potato growers were interviewed at their village homes during the month of September, 2011. Potato traders were interviewed at cold storage premises during the month of September, 2011, when they came to store potato. Data relating to cold storage plants were collected from owners and/or management personnel of the respective selected plants. For getting accurate data several, visits were made both at site and head offices of the selected cold storage plants during
study.Secondary data were collected from different published and unpublished materials and related organization like Department of Agricultural Marketing of Bangladesh and Bangladesh Cold Storage Association (BCSA). The filled up interview schedules were scrutinized and edited in order to remove any ambiguities and inconsistencies of collected data. The collected data were then transferred to Excel-sheets, compiled and summarized from each form to facilitate tabulation. Qualitative data were converted into quantitative one by means of suitable scoring. A list of tables was prepared in accordance with the aims and objectives of the study. Mainly descriptive statistics were applied for the analysis of data to obtain the result. Ratio to moving average method was used to examine the seasonal price variation of potato in Rangpur district from the period of 2000 to 2010. Monthly wholesale prices of potato were used to apply this method.

\section{Results and Discussion}

\subsection{Storage system}

Capacity utilization of sampled plants, sources of preserved potatoes, grading of potatoes and its storing, extent of potato damaged in and quantity not taken back from cold storage plants, pattern of buying and selling of potato by plant owners have been discussed under the storage system of potato.

\subsubsection{Capacity Utilization of Sampled Plants}

In the year 2010,97000 tons of potato was preserved in 10 sampled plants against the potential storage capacity of 97000 tons i.e. 100 percent capacity was utilized. The average potential capacity was 9700 tons which varied from 4000 to 16000 tons per plant and the average quantity of potato stored was 9700 tons (Table 1). About 42 percent of the total quantity of potato was stored in 4 plants having a total storage capacity of 41000 tons varying from 8001-12000 tons per plant.

\subsubsection{Sources of Preserved Potato}

Storing of potato was done in two ways by the plant owners; one was storing of self-purchased potato and the other was hiring out of storage space to others on receipt of charges. Hiring facilities of storage space was made available both to the growers and the traders. The rate of cold storage charge was fixed by the Bangladesh Cold Storage Association at Tk. 3273.80 per m. ton [Tk.275/sack ( $84 \mathrm{~kg}$.)] of potato in 2010. The rate of charge was declared before the beginning of storage period. 
Table 1. Distribution of cold storage plants according to potential capacity and capacity utilized in 2010

\begin{tabular}{|c|c|c|c|c|}
\hline $\begin{array}{c}\text { Range in potential } \\
\text { storage capacity (in tons) }\end{array}$ & Number of plants & $\begin{array}{c}\text { Potential capacity } \\
\text { (tons) }\end{array}$ & $\begin{array}{c}\text { Utilized capacity } \\
\text { (tons) }\end{array}$ & $\begin{array}{c}\text { Capacity utilized as } \\
\text { percentage of potential } \\
\text { capacity }\end{array}$ \\
\hline $4000-8000$ & $4(40.0)$ & $25000(26)$ & $25000(26)$ & 100.00 \\
\hline $8001-12000$ & $4(40.0)$ & $41000(42)$ & $41000(42)$ & 100.00 \\
\hline $12001-16000$ & $2(20.0)$ & $31000(32)$ & $31000(32)$ & 100.00 \\
\hline Total & $10(100.0)$ & $97000(100.00)$ & $97000(100.00)$ & 100.00 \\
\hline Average capacity & & 9700 & 9700 & 100.00 \\
\hline
\end{tabular}

Figures within parentheses indicate percentages of total.

Table 2. Cold storage plants and quantity stored according to sources of potato

\begin{tabular}{|c|c|c|c|c|}
\hline \multirow{2}{*}{ Sources } & \multicolumn{3}{|c|}{ Quantity of stored potato (tons) } & \multirow{2}{*}{$\begin{array}{c}\text { Percent of the total stored } \\
\text { potato }\end{array}$} \\
\cline { 2 - 4 } & Table potato & Seed potato & Total & 32.32 \\
\hline Plant owners & $9550(30)$ & $21800(70)$ & $31350(100)$ & 45.00 \\
\hline Traders & $31200(71)$ & $12450(29)$ & $43650(100)$ & 22.68 \\
\hline Growers & $14050(64)$ & $7950(36)$ & $22000(100)$ & 100.00 \\
\hline All sources & $5480056)$ & $42200(44)$ & $97000(100)$ & \\
\hline
\end{tabular}

Figures within parentheses indicate percentages of total.

Table 3. Purchase of potato by traders from different sources (in tons)

\begin{tabular}{|c|c|c|c|c|c|c|}
\hline Traders & Growers & Farias & Beparies & Paiker & CSO & Total \\
\hline Farias & $175(100)$ & - & - & - & - & $175(100)$ \\
\hline Bepari & $1960(60)$ & $1280(40)$ & - & - & - & $3240(100)$ \\
\hline Paiker & $18100(40)$ & $14900(33)$ & $12600(27)$ & - & - & $45600(100)$ \\
\hline CSO & $11500(52)$ & $6200(28)$ & $4300(20)$ & - & - & $22000(100)$ \\
\hline Retailers & $1230(11)$ & $550(5)$ & $2100(18)$ & $5000(44)$ & $2500(22)$ & $11380(100)$ \\
\hline All sources & $32965(40)$ & $22930(28)$ & $19000(23)$ & $5000(6)$ & $2500(3)$ & $82395(100)$ \\
\hline
\end{tabular}

Figures within parentheses indicate percentages of total; CSO: Cold storage owner

Source wise distribution of the total preserved potato in 10 plants is shown in Table 2. Potato growers preserved 22.68 percent of the total stored quantity of potato in all the plants. Potato traders were observed to store the highest quantity in 10 plants which accounted for 45 percent of the total stored potato. No trader was found to store potato in one plant. Cold storage owners preserved only 32.32 percent of the total quantity in 10 plants which was the lowest as compared to the quantity preserved by traders and higher than that of growers. Table 2 also reveals that both table and seed potatoes were stored in all the plants. Fifty six percent of the total quantity was table potato and the remaining 44 percent was seed potato.

\subsubsection{Purchasing and Selling Pattern of Potato by Different Intermediaries}

Cold storage owners purchased potato at their plant premises from both the growers and the traders during March to April at market price. They purchased potato from different rural markets, farmers' premises and traders at the prevailing market price.

The potato purchased by the plant owners must be of cold storage quality which meant that those would be of even size, disease free and free from mechanically insured and bruised potatoes were usually sorted out before storing.Plant owners purchased 52 percent and 48 percent of the total quantity of potato from farmers and traders respectively (Table 3 ). Nine plant owners purchased 11500 tons of potato from the growers and the average quantity purchased from growers was 1277.77 tons per plant. Eight plant owners purchased 10500 tons of potato from the traders and the average quantity purchased from traders was 1312.50 tons per plant (Table 4). All the 10 plant owners were found to have purchased potatoes from more than one source. Buying of potato from the growers was the highest which indicates that the growers were deprived of getting higher prices for their potato at harvest time. 
Table 4. Quantity of potato purchased by the plant owners according to buying sources

\begin{tabular}{|c|c|c|c|c|}
\hline \multirow{2}{*}{$\begin{array}{c}\text { Buying sources } \\
\text { (From whom bought) }\end{array}$} & \multirow{2}{*}{ Number of plants } & \multicolumn{2}{|c|}{$\begin{array}{c}\text { Quantity of potato purchased } \\
\text { (in tons) }\end{array}$} & $\begin{array}{c}\text { Proportion of the total } \\
\text { quantity } \\
\text { (in percent) }\end{array}$ \\
\cline { 2 - 5 } & & Total & Average per plant & 52.27 \\
\hline Growers & 9 & 11500 & 1277.77 & 47.73 \\
\hline Traders & 8 & 10500 & 1312.50 & 100.00 \\
\hline All sources & 9 & 22000 & 2444.44 & \multirow{2}{*}{} \\
\hline
\end{tabular}

Note: 1 plant owners did not preserve any self-purchased potato.

\subsubsection{Grading of Potato and Its Storing in Cold Storages}

Grading of potato was done in all the cold storage plants before storing and is defined to be the sorting of potato of according to some standards. However, there is no officially initiated and implemented grading and sorting method for potato in Bangladesh. In all the cold storage plants grading was done according to the purchase and use of potato and the process was based on eye estimation of potato. The number of grader used for potato was found to vary among plants from 3 to 5 according to the size of potato. The grades were sampled as grade I, II, III, IV and V in those plants where used. All these grades were determined by eye estimation and no standard mechanism was followed in any of the cold storages that were studied. In case of plant using 5 grades, potato of grade I and II were large in size which were mostly used for culinary purposes and termed as "table potato". Potato of grade III were medium sized and stored for both table and seed purpose. Conversely, in cases of plants using three grades; grade I, II and III were large, medium and small sized potatoes, respectively. Grade I was stored for table purposes; grade II was stored for both table and seed purposes; and grade III was stored for seed purposes only. Potatoes which were small and even sized, bright color, disease free, unbury and free from mechanical injury were generally selected for seed purpose.

After collection and grading of the potato some routine regulations and practices were followed in all the cold storages before and after storing period. Diseased, mechanically injured and bruised potato were sorted out before storing. Pre-cooling of the potato was sorted out before storing at a temperature of $48^{\circ} \mathrm{F}$ for 24 hours in case of table potatoes and for 7 days in case of seed potato. Then the pre-cooled potato was kept in gunny bags, stacked on wooden racks inside the plants and stored at $48^{\circ}-50^{\circ} \mathrm{F}$ temperature and 80 to 90 percent relative humidity. The stored potato was checked at different times during the whole storage period and the gunny bags were again put at $48^{\circ}-50^{\circ} \mathrm{F}$ temperature for 24 hours and then dried under electric fan for 5 to 6 hours at adjacent premises. After releasing, the seed potato was required to be kept in shady place for at least 7 days before selling to reject diseased, physically disordered and sprouted potatoes to be sold at higher prices.

\subsubsection{Extent of Potato damaged in Cold Storage Plants}

All the plant owners reported that a portion of the total cold stored potato was damaged almost every year in Bangladesh. According to them damage of potato may be categorized into two types depending upon the nature and causes of damage- one is normal and other is uncertain damage. Normal damages are common to every plant which occurs in terms of quantity shortfall due to shrinking, physiological disorders, storage diseases and sometimes sprouting of tubers. Uncertain damages occur in terms of rotting of stored potato. The probable causes responsible for damages are mechanical trouble or machinery breakdown, collapse of cold storage building, breakage of racks and power supply disruption for comparatively longer period of time. The quantity of stored potato damaged in the sampled plants was estimated by adding only normal damage of self-stored potato of plant owners with uncertain damages of stored potato that occurred in the sample plants in 2010 . The damaged quantity of the potato preserved by the plant owners was estimated by the difference between the total quantity purchased by them and the total quantity of self-purchased potato that was sold. Uncertain damage included only that quantity which was reported to be damaged in the sample plants due to collapse of plant building, machinery breakdown and power supply disruption. Hence the extent of potato damage was found to be 2.75 percent if the normal damages of potato preserved by the growers and the traders could also be estimated and included in the above estimate.

\subsubsection{Pattern of Sale of Potato by Plant Owners}

The plant owners reported that they started selling of their self-stored potato in the month of July and continued up to December. Table potatoes were sold every month during the period from July to December and seed potatoes were sold during the period from September to December. Quantity of potato sold during the month of October was the highest in case of both seed and table potatoes which together accounted for 23 percent of the total quantity sold (Table 5). 
Table 5. Distribution of quantity of potato sold by plant owners in different months

\begin{tabular}{|c|c|c|c|c|}
\hline \multirow{2}{*}{ Month } & \multicolumn{3}{|c|}{ Quantity of potato sold } & \multirow{2}{*}{$\begin{array}{c}\text { Percent of proportion to the total } \\
\text { quantity sold }\end{array}$} \\
\cline { 2 - 4 } & Table potato & Seed potato & Total & 14.94 \\
\hline July & $3250(17)$ & 0 & 3250 & 14.25 \\
\hline August & $3100(16)$ & 0 & 3100 & 13.79 \\
\hline September & $2750(14)$ & $250(11)$ & 3000 & 23.00 \\
\hline October & $4000(20)$ & $1000(44)$ & 5000 & 21.38 \\
\hline November & $3850(20)$ & $800(36)$ & 4650 & 12.64 \\
\hline December & $2550(13)$ & $200(9)$ & 2750 & 100.00 \\
\hline All months & $19500(100)$ & $2250(100)$ & 21750 & \\
\hline
\end{tabular}

Figures within parentheses indicate percentages.

Table 6. Distribution of quantity of self-stored potato sold by plant owners according to selling sources

\begin{tabular}{|c|c|c|c|c|}
\hline \multirow{2}{*}{$\begin{array}{c}\text { Selling sources (To } \\
\text { whom sold) }\end{array}$} & \multicolumn{3}{|c|}{ Quantity of potato sold (tons) } & \multirow{2}{*}{$\begin{array}{c}\text { Percent of the total quantity } \\
\text { sold }\end{array}$} \\
\cline { 2 - 5 } & Table potato & Seed potato & 1050 & 4.80 \\
\hline Growers & 0 & $\begin{array}{c}1050 \\
(24)\end{array}$ & 8920 & 41.0 \\
\hline Beparies & $\begin{array}{c}7700 \\
(44)\end{array}$ & $\begin{array}{c}1220 \\
(29)\end{array}$ & 7285 & 33.5 \\
\hline Retailers & $\begin{array}{c}6400 \\
(37)\end{array}$ & $\begin{array}{c}885 \\
(21)\end{array}$ & 4495 & 20.7 \\
\hline Wholesalers & $\begin{array}{c}1125 \\
(26)\end{array}$ & $\begin{array}{c}4280 \\
(100)\end{array}$ & 21750 & 100.00 \\
\hline All sources & $\begin{array}{c}17470 \\
(100)\end{array}$ &
\end{tabular}

Figures within parentheses indicate percentages.

Table 5 also reveals that quantity sold in the month of December was the lowest which accounted for only 12.64 percent of the total quantity. Potato that was sold during the months of October and November contributed 44.38 percent of the total quantity. Prices of potato became relatively higher during these months because of increased demand for cold stored potato to be used as seed. Quantity of table potato sold during July to December did not vary too much from month to month.Distribution of quantity of self-stored potatoes sold by the plant owners according to the sources of sale is shown in Table 6. Plant owners sold about 41 percent of their potatoes to Beparies. Both the quantities of table potato sold to Beparies were the highest which accounted for 44.10 percent of the table potato and 28.50 percent of the seed potato respectively. Plant owners sold only 4.80 percent to the grower which was only seed potato ( 24.50 percent of the seed potato). They sold 33.5 percent of the total quantity through retailers of which 6400 tons were table potato and 885 tons were seed potato. About 20 percent of table potato and 27 percent seed potato were sold to wholesalers which together constituted 20.70 percent of the total potato sold by the plant owners.

The plant owners reported that they sold potato to the Beparies and the growers at plant premises only. They sold to the wholesalers and retailers both at plant premises and buyers premises. Most of the plant owners reported that they sold potato through retailers on payment of commission and in some cases the retailers purchased potato from plant owners directly on payment of cash money. In case of outside sale, the plant owners contacted the buyers of potato, fixed the prices of potato and accordingly supplied the outside contact sales, transportation costs were provided by the plant owners. No transportation cost was provided by the plant owners when potato was sold at the plant premises. Prices of potato were determined at the time of sale considering the prevailing market rate.

\subsection{Seasonal Price Variations:}

It is evident from Table 7 that during 2000 to 2010 , potato price was the highest (128.55) in the month of December i.e. price becomes about 29 percent higher than the average price in this month and lowest (75.26) in the month of March i.e. price becomes 25 percent lower than the average price in this month. Prices began to increase by April and reached the peak in December. During the harvest period, potato price remained low and then it gradually rose up to the start of next harvesting period. The co-efficient of variation of price indices was 18.48 percent. Lowest price of potato was observed in March during the period of 2000 to 2005. Price began to increase by April, reach the peak in December and thus produced a co-efficient of variation of 19.19 percent. On 
the other hand, potato price was found to be lowest in the iii. month of March for the period of 2006 to 2010. Here is a noticeable thing that the price pattern remains constant in three periods of time (Figure 1). There was no change in the month of highest price and lowest price. March is the lowest price for all the periods and December is the highest price for all the periods also. And the coefficient of variations is more or less same over the two periods that means price variation between the three periods are closer to each other. In general it was found that the price of potato fluctuated in different seasons and also in different months and years. The causes of this fluctuation might be:

i. Supply of potato comes to an end in

November-December especially in November but the demand remains unchanged and also the rises.

ii. Also in the part of the season, the farmers lack seed potato. So the price of potato begins to rise.
The cause of falling prices of potato in February is that the supply of potato was higher (because of harvesting season) than its demand. In this time other winter vegetables become easily available and the price of potato begins to fall gradually.

But this seasonal price fluctuation can be maintained in a tolerable range by improving the storage system. In December, Percent of proportion to the total quantity of potato sold by plant owners was lowest (12.64 percent). On the other hand, the seasonal price index was highest in that month for all periods (Table $5 \& 7$ ). To maintain a stabilize price throughout the year, proper storage is needed in those months when price is lower for excess market supply (February, March, April) and stored potato should be marketed in those months when price is higher for supply shortage (November, December).

Table 7. Seasonal price indices of potato

\begin{tabular}{|c|c|c|c|}
\hline Index & Seasonal indices (2000-2005) & Seasonal indices(2006-2010) & Seasonal indices(2000-2010) \\
\hline Month & 97.91 & 89.23 & 96.48 \\
\hline January & 76.17 & 73.80 & 75.28 \\
\hline February & 76.00 & 71.50 & 80.56 \\
\hline March & 79.00 & 80.25 & 86.34 \\
\hline April & 85.50 & 86.85 & 90.40 \\
\hline May & 90.00 & 92.32 & 101.36 \\
\hline June & 100.37 & 99.81 & 108.96 \\
\hline July & 107.52 & 111.21 & 112.40 \\
\hline August & 112.08 & 114.73 & 123.51 \\
\hline September & 120.52 & 120.60 & 128.55 \\
\hline October & 124.40 & 127.40 & 128.55 \\
\hline November & 130.53 & 132.30 & 75.26 \\
\hline December & 130.53 & 132.30 & 53.29 \\
\hline Highest & 76.00 & 71.50 & 18.48 \\
\hline Lowest & 54.53 & 60.80 & 20.88 \\
\hline Range & 19.19 & & \\
\hline Co-efficient of variation (\%) & & & \\
\hline
\end{tabular}

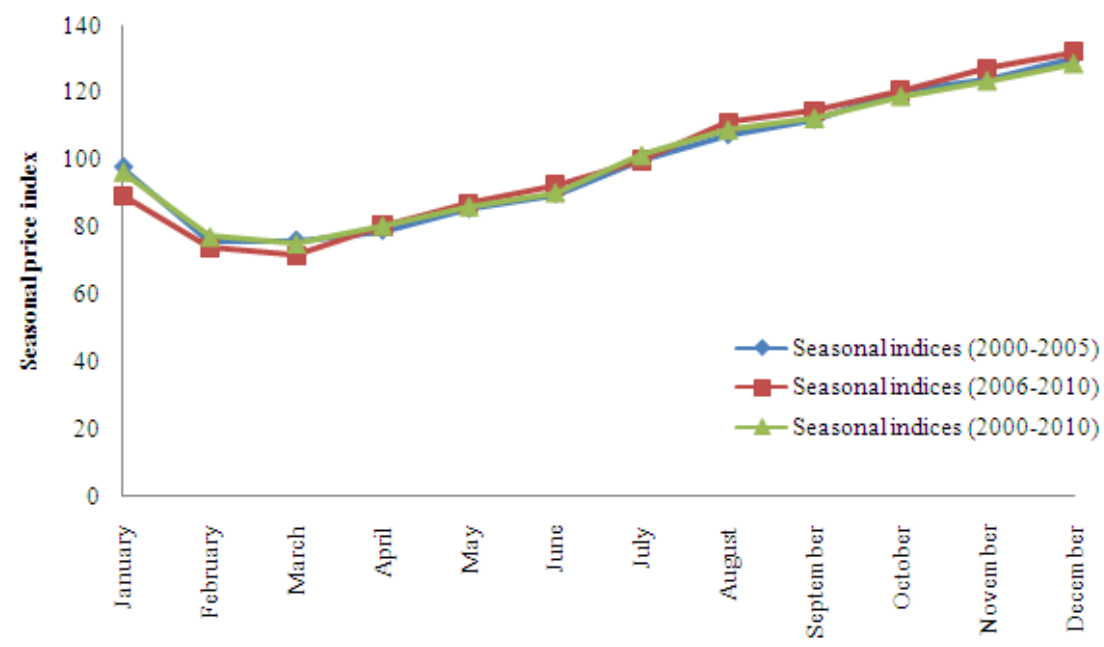

Figure 1. Seasonal price variation of potato 


\section{Conclusion}

The production of potato in Bangladesh is greatly influenced by many post-harvest problems such as storage, price fluctuation; demand for potato etc. lack of cold storage facilities, potato is shriveled, rotten or sprouted causing huge loss of potato under normal temperature and humidity. Since the prevailing cold storage charge is too high, all farmers can not avail the facility of cold storages due to their financial insolvency. As a result, farmers are compelled to sell a major portion of their produce during harvest time relatively at lower prices. The price becomes very low during peak harvesting period while it becomes too high before planting period. Frequent undue price fluctuations create uncertainty about the market price and enhance risks in potato production as well as potato business. For stabilizing potato prices, forecasting of potato prices and target production should be made in time before sowing, so that the farmers can adjust potato acreage accordingly. With successful operation of a buffer stock, price instability may be reduced. Government intervention in potato marketing is necessary to ensure fair price to the farmers by controlling such unexpected price fluctuations. Therefore, in order to ensure storage of potato in cold storage plant by the framers and normal supply of potato in the slack season, cold storage charges should be reduced to a certain level safeguarding the interests of both the farmers and plant owners.

\section{REFERENCES}

[1] M. T. Islam, “An Economic Study of Potato Preservation in
Cold Storage in Some Selected Areas of Bangladesh", Unpublished M.Sc. Thesis submitted to the Department of Cooperation and Marketing, Bangladesh Agricultural University, Mymensingh. Bangladesh, 1987.

[2] H.C. Thompson, and W.C. Kelly, Vegetable crops, McGraw Hill Book Company Inc., New York, 1957.

[3] K.U. Ahmad, "Potato for the Tropics", Published by Mamtaj Kamal, Bunglow No. 2, Krishi Khamar Sharak, Farmgate, Dhaka, 1977.

[4] M.A. Siddique, and M.M. Hossain, Production of Local Potato Varieties (in Bengali), Bangladesh-Netherlands Seed Multiplication Project, BADC, Dhaka, 1988.

[5] K. U. Ahmad, "Potato Post-harvest Technology", Proceedings of the $2^{\text {nd }}$ Workshop of Potato Research Workers, Bangladesh Agricultural Research Institute (BARI), Joydebpur, Dhaka, 1979.

[6] Kh. M. O. Rahman, "Technology of Drying for Long Term preservation of Potato", Proceedings of the $4^{\text {th }}$ workshop of Potato Research workers. Joydebpur, BARI, Bangladesh, 1981.

[7] K. U. Ahmad, "Post-harvest Problems of Potato". Proceedings of the $3^{\text {rd }}$ Workshop of Potato Research Workers, (BARI) Joydebpur, Dhaka, 1980.

[8] M. Alauddin, "How to Increase Cold Storage Capacity in Bangladesh", Proceedings of the $2^{\text {nd }}$ Workshop of Potato Research Workers. BARI, Joydebpur. Bangladesh, 1979.

[9] A. A. Khan, S. Rahman, and G. Kamaluddin, "A Preliminary Survey of the Diseases of Potatoes in Cold Storages in Bangladesh", Bangladesh Journal of Biological and Agricultural Science. Vol.2, No.2, 1973.

[10] G. A. Fakir, "Storage Diseases of Potato", Proceedings of the 2nd Workshop of Potato Research Workers, BARI, Joydebpur, Bangladesh, 1979. 